\title{
Corporate brand building from the corporate stories perspective: a Brazilian football teams study
}

\author{
EDSON ROBERTO SCHARF \\ UNIVERSIDADE DE BLUMENAU (FURB), BLUMENAU - SC, BRAZIL \\ Francisco GIOVANNI DaVID VieIRA \\ Universidade Estadual de Maringá (UEM), Maringá - PR, BRAZIL \\ Richard Perassi luiz de SOUSA \\ UNIVERSIDADE FEDERAL DE SANTA CATARINA (UFSC), FLORIANÓPOLIS - SC, BRAZIL
}

EDIMAR RUSSI

UNIVERSIDADE DE BLUMENAU (FURB), BLUMENAU - SC, BRAZIL

\begin{abstract}
The study aims to investigate the content of corporate stories of the Brazilian's football clubs and how these stories are used to build their corporate brands. The stories were collected from the corporate websites of football clubs in Brazil belonging to series A, B and C. A qualitative analysis of the corporate stories was carried on by means of content analysis of the corpus resulting from them. The results showed that emotion is a key element and is most strongly represented in the websites. The findings also revealed that although the clubs work with human talent, and positive results of the teams in the pitch are dependent on talent, this important aspect is practically forgotten on the websites. Academic and managerial implications, as well as limitations of the study are presented at the end.
\end{abstract}

Keywords: Corporate brand. Corporate stories. Branding. Football clubs. Content analysis.

A construção de marcas corporativas por meio da perspectiva das corporate stories: um estudo dos times de futebol brasileiros

\section{Resumo}

O estudo tem como objetivo investigar o conteúdo das corporate stories de clubes de futebol do Brasil e como elas são usadas para construir suas marcas corporativas. As corporate stories foram coletadas nos sítios corporativos de todos os clubes de futebol no Brasil, pertencentes as séries A, B e C. A análise qualitativa das corporate stories foi realizada por meio de análise de conteúdo. Os resultados mostraram que a emoção é um elemento-chave e é o mais fortemente representado nos websites. Os resultados também revelaram que, embora os clubes trabalhem com capital humano, e os resultados positivos das equipes no campo são dependentes deste talento, este aspecto é praticamente esquecido nos sítios. Implicações acadêmicas e gerenciais bem como limitações do estudo, são apresentadas no final.

Palavras-chave: Marca corporativa. Corporate stories. Marcas. Clubes de futebol. Análise de conteúdo.

La construcción de marcas corporativas a través de la perspectiva de historias corporativas: un estudio de los equipos de fútbol de Brasil

\section{Resumen}

El estudio tiene como objetivo investigar el contenido de las historias corporativas de los clubes de fútbol de Brasil y cómo estas se utilizan para construir sus marcas corporativas. Las historias corporativas se recogieron de los sitios web corporativos de todos los clubes de fútbol de Brasil, pertenecientes a las series A, B y C. Se realizó el análisis cualitativo de las historias corporativas a través de análisis de contenido. Los resultados mostraron que la emoción es un elemento clave y es el más fuertemente representado en las páginas web. Los resultados también revelaron que, aunque los clubes trabajen con capital humano y los resultados positivos de los equipos en campo dependen de ese talento, este aspecto prácticamente no es considerado en los sitios web. Las implicaciones académicas y de gestión, así como las limitaciones del estudio, se presentan al final.

Palabras clave: Marca corporativa. Historias corporativas. Marcas. Clubes de fútbol. Análisis de contenido. 


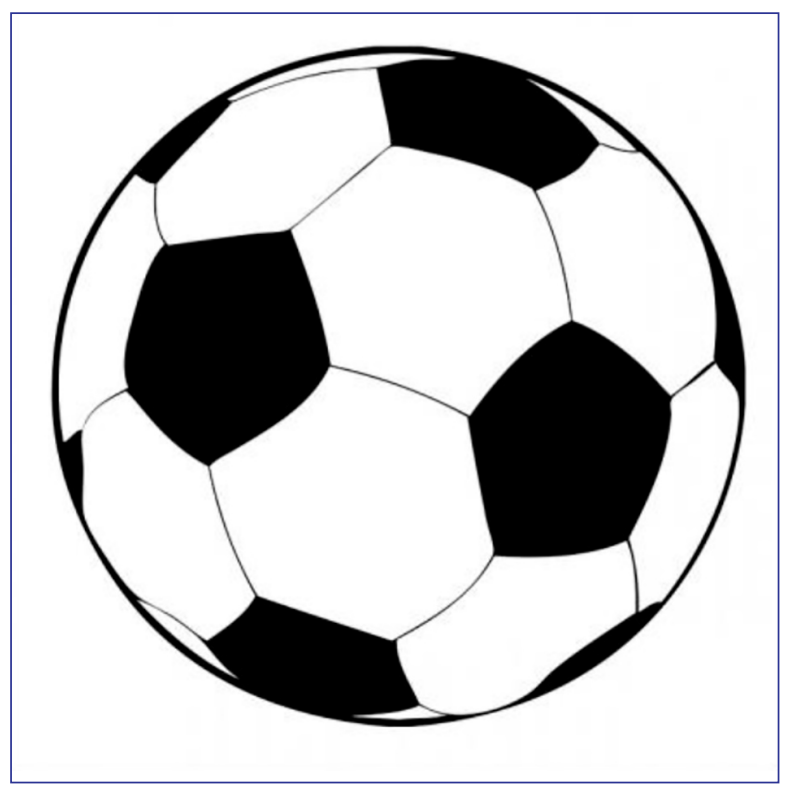

\section{INTRODUCTION}

Football is a national passion in Brazil: there are more practitioners, more viewers, higher values of greater media visibility and sponsorship than in any other sports in the country. With teams having up to 40 million fans, their brands allow them to get advertising dollars for investment in physical infrastructure as well as in athletes.

In this sense, the football team's corporate brand is very significant. It is what appears on the flags in the stadiums, commemorative jerseys worn by fans, as well as accessories like wallets or key chains. The brand carries the pride that the fans have for their team, and strengthens the identification they have with the teams' projected values.

This brand identification can be obtained from various sources, such as parents, friends or TV broadcasting. One of the areas of interest of study to differentiate the various corporate brands' football teams is the use of the technique called corporate stories. For Janssen et al. (2012), storytelling helps to demonstrate the importance of corporate brand to internal and external stakeholders using different forms, and the corporate story is one of them.

Although football and the business around it is characterized as an important source and reference to branding activities, which consists of millions of people and represents investments of billions of dollars, there is a gap in the literature about how football teams use the content of corporate stories to build their corporate brands. Important studies have been published in recent years (DOWLING, 2006; ABRATT and KEYN, 2012; FETSCHERIN and USUNIER, 2012; ROPER and FILL, 2012), but none address this subject.

\footnotetext{
* Source: Pixabay. Available at: <https://pixabay.com/pt/bola-de-futebol-futebol-black-22O205/>. Accessed on January 17, 2017
} 
This paper aims to contribute to filling this gap. To do so, it investigates the content of corporate stories of football teams in Brazil and how these stories are used by clubs to build their corporate brand. In the following section, the theoretical foundation is presented. Subsequently, the methodological procedures of the study are pointed out, and the results are presented and discussed. At the end, limitations and considerations are proposed with regard to the academic and managerial implications of this study.

\section{THEORETICAL BACKGROUND}

In order to present the theoretical background of this paper, the next subsections approach corporate stories and corporate storytelling. At the end of the section is made a synthesis of the theory that guides the analysis.

\section{CORPORATE STORIES, CORPORATE STORYTELLING AND NARRATIVE TRANSPORTATION: FROM PERSUADING THE CONSUMER TO THE CORPORATE BRAND DEVELOPMENT}

According to Roper and Fill (2012), communication is a technique used by organizations to demonstrate the corporate brand to internal and external audiences, with the aim of creating a competitive position in relation to rivals. For several authors (BROWN et al., 2006; DOWLING, 2006), the reputation of the organization is defined by the internal and external stakeholders' perception of the entity. It is the corporate brand that produces and shares this reputation, because its connotation tells stories to the public through various means, usually through narratives.

Some authors (MacINNIS and JAWORSKI, 1989; CUNLIFFE et al., 2004; LING et al., 2010) argue that there are divergent meanings for corporate stories and corporate storytelling. While the corporate stories have temporality and consistency, corporate storytelling or narratives do not always present coherent plots in their development.

In this sense, several authors (ESCALAS, 2007; WYER and XU, 2010) propose two different ways of thinking, analytical and narrative, and both influence persuasion. The focus of analytical thinking, the basis of corporate stories, is to logically compare generated alternatives in a systematic way. The narrative processing model says consumers often create and use stories to make decisions and understand the meaning of their experiences with products and brands. For Wyer and Xu (2010) and Mai and Schoeller (2009), narrative thinking is an experience in which the viewer or reader constructs meaning through a process of interpretation, attribution, imagery and emotion.

Corporate storytelling is effective in changing attitudes and beliefs because of its ability to transport people to different realities. To Escalas (2007), the imagination can influence the evaluation of products by transporting consumers to distant realities. When a person thinks using narratives, he or she can be transported with an emphasis on persuasion, often without making an analytical review of the arguments of advertising messages (ESCALAS, 2007). However, the author's research points to the strength of the argument as having an impact on brand evaluation when consumers have not used their imagination on their experience with the product. Nevertheless, it had not an impact when respondents were involved in the experience.

Narrative transportation can affect brand evaluation and persuasion. Initially, strong feelings associated with the story can be transferred to the brand (ESCALAS, 2007). Then the scenes presented in the commercial evoke the imagery that connects the experience of integrating the meaning of the narrative, building beliefs about the brand (ESCALAS, 2007). Finally, the transportation process can make a story seems a more real experience and, because of that, can strongly influence consumer attitude (MacINNIS and JAWORSKI, 1989; ESCALAS, 2007).

Whereas the increase in effort during analytical processing leads to a more critical evaluation of options to choose from, the will to exert mental effort during the narrative leads to increased transportation (ESCALAS, 2007), and leads to a strong emotional response to a narrative and the experiential (GASKI and ETZEL, 1986). Green et al., (2008) warns, while greater transportation leads to greater persuasion, better analytical development can impair persuasion. 


\section{CORPORATE STORIES: A PATH TO ORGANIZATIONAL REPUTATION}

For Collins (2013), corporate stories are different forms of narrative and are developed in various ways to positively persuade consumers about the brand. According to MacInnis and Jaworski (1989), Cunliffe et al., (2004) and Ling et al., (2010), corporate stories are events reported logically (coherence) and chronologically (temporality). These events may include heroes, villains, myths, fantasies, and actions of courage, sacrifice and trials, as reminded by Brown et al., (2009), indicating that some corporate stories may have occurred differently from how they are eventually presented. According to Van Riel and Fombrun (2007), the communication creates in the stakeholders a sense of goodwill, increasing the value of reputation. The reputation shows that the organization fulfills the promises made, affecting purchasing decisions, since there is development of strong emotional associations between the company and consumers.

At other times, corporate stories are reflections of the story organization's own history, spreading only attributes that the organization already possesses, without creating new issues (SRINIVASAN et al., 2010). For the author, proper corporate stories should emphasize current or former attributes that drive the company's reputation. Authors (BAKER and BOYLE, 2009; WOODSIDE, 2010; WYER and XU, 2010; JANSSEN et al., 2012) have presented several elements that form a platform for reputation. Common themes are Activities, Benefits and Emotions. In a corporate story the theme Activities consists of a description of the organization's activities, skills, abilities and accomplishments (WOODSIDE, 2010). Core activities of the company are part of the theme Activities of corporate stories, according to Janssen et al. (2012). Some authors (PORTER, 1985; SRIVASTAVA, 1998) consider aspects such as vision, mission and values part of organizational competencies. According to Van Riel and Fombrun (2007), communication is best exercised to meet the expectations of stakeholders when the organization adopts a single line of reasoning to its corporate history. For these authors, this line of communication must serve both internal and external actions. Therefore, for the purpose of this study, they are in theme Activities.

The theme Benefits, in corporate stories, represents results that attract or that stakeholders can expect from the organization's activities (BAKER and BOYLE, 2009; WOODSIDE, 2010). Benefits can be common or customized, and the organization must decide whether it will build corporate stories in mass communication format or individual format for certain groups (BAKER and BOYLE, 2009). Several authors (FETSCHERIN and USUNIER, 2012; SUVATJIS et al., 2012) argue that internal and external communications are equally important in creating a strong corporate reputation, though Suvatjis et al., (2012) understand that benefits targeting internal and external stakeholders should be considered as separate elements of theme Benefits.

The theme Emotions in corporate stories establishes an emotional link with stakeholders to obtain a personal connection. Authors such as Brown et al., (2009) and Roper and Fill (2012) emphasize that a corporate brand can display the battles the organization has had and how problems were solved, to add emotion and audience involvement. To do so, conflicts are identified in the storytelling literature as key elements of stories, in the form of hardship and difficulties, and what steps were taken to overcome the situation, according to the understanding of Woodside (2010) and Fetscherin and Usunier (2012). Several authors (MAY and SCHOELLER, 2009; ABRATT and KEYN, 2012; COLLINS, 2013) argue that an emotional theme in stories has not always benefited credibility due to its fanciful content, but when there is emotional involvement, the results tend to be more intense towards the brand.

\section{WHAT IS THE PURPOSE OF CORPORATE STORIES?}

When organizations want internal and external stakeholders to understand their values and, as a result, establish a positive reputation for the brand, they seek a number of aids to meet their objective. According to Van Riel and Fombrun (2007), corporate reputation is a collective representation of actions and activities of the organization and its results, which demonstrates the ability to generate value to the various stakeholders. Complementarily, Gupta (2012) suggests that are testimonials from opinion leaders and celebrities, unique message content, corporate stories and comparative information with other organizations. Each of these types of aid has its own characteristics and can obtain different results depending on certain situations, such as the time limit for the event or the budget set for the campaign. Due to its specific nature, corporate stories are effective when there is a gap between the organization's intentions and actions. Corporate stories can be effective in building a strong corporate brand (SRINIVASAN et al., 2010). 
Corporate stories offer benefits when sharing knowledge about a brand because they help stakeholders to organize and understand communicated/shared/released information (DOWLING, 2006; BAKER and BOYLE, 2009; WOODSIDE, 2010). According to Baker and Boyle (2009), the most important role of these benefits is to evoke emotions, and generating positive connections with the brand. On the other hand, according to Ling et al., (2010), emotions attract attention and arouse strong feelings in stakeholders when communicating information related to corporate brand, and Dewaele (2004) points out that emotions create vivid memories about the brand.

In that sense, Cunliffe (2004) draws attention that emotions can be used in corporate stories to develop or solidify a brand's image. The author argues that brand identity can also benefit from communicating functional benefits along with emotional ones. Corporate brand can also be enhanced if stories are told relating to it.

Internally, corporate stories can be effective in communicating with employees, primarily to engage them and in order that they understand their role within the company. To Chernatony et al., (2006) besides offering an understanding of their importance as employees within the organization, corporate stories can influence employees' actions towards corporate culture.

\section{SYNTHESES CONSIDERATIONS ON THE THEORETICAL FOUNDATION}

In order to build a strong corporate brand, the organization can adopt several approaches. One of the possibilities of creating a relationship between internal and external stakeholders with the reputation of the corporate brand is through corporate stories. With the ability to use functional and emotional attributes for storytelling, this study uses elements that can more properly create the corporate stories. These elements are called Activities, Benefits and Emotions. They can be used together or individually to create the corporate stories, with the goal of building corporate brands (Figure 1).

Figure 1

\section{Corporate brand building by means of corporate stories}

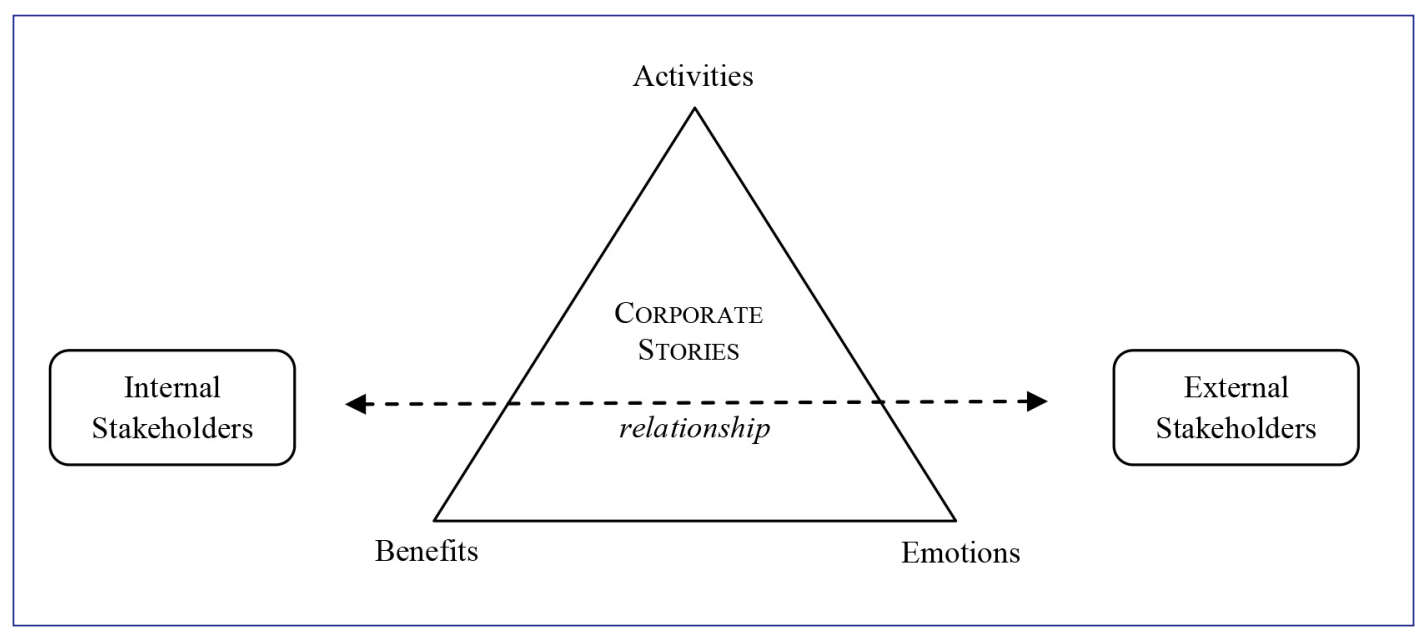

Source: Elaborated by authors. 


\section{METHODOLOGICAL PROCEDURES}

This study aims at investigating the content of corporate stories present on web sites of football clubs in Brazil belonging to series $A, B$ and $C$, and how these stories are used to develop their corporate brand.

The set of Brazilian football teams in series A, B and C, is rated by CBF - Football Brazilian Confederation, the largest entity of the sport in the country, subject to FIFA - Fédération Internationale de Football Association rules. The "series" are equivalent to the first, second and third divisions of international football. There are 60 teams, divided into 20 teams per series. Each year, the top four ranked teams in their series go up to the next one, with the exception of Series A, since it is the first. In the same period, the four teams with the lowest scores in their series go down to the previous series.

The format for conducting the study, which took place between January and April 2014, is a census, and the population corresponds to Brazilian teams divided into groups according to CBF. Content analysis technique (KRIPPENDORFF and BOCK, 2008) was used for corpus analysis. Bardin (2010) argues that the technique is used to describe and interpret the content of all types of documents and text, using systematic descriptions to help reinterpret the messages conveyed and to gain an understanding of their meanings. As Durial et al. (2007) stand, content analysis is a technique for reading and interpreting documents. If conducted properly, it allows for uncovering phenomena of social life that can be difficult to access otherwise, since the technique allows understanding of shared meanings on a level that goes beyond ordinary reading.

In view of this understanding, the units of record used in this study were adapted from the findings from Spear and Roper (2013), who studied corporate stories on the websites of 99 for - and not - profit organizations. Thereby, the units of record defined for this study are Activities, Benefits and Emotions, as can be seen in Chart 1.

\section{Chart 1}

\section{Units of record used for analysis}

\begin{tabular}{|l|l|}
\hline Units of Record & Definition \\
\hline Activities & Description of activities, skills, abilities and accomplishments of the organization \\
\hline Benefits & $\begin{array}{l}\text { Results that attract or that stakeholders can expect from the organization's } \\
\text { activities }\end{array}$ \\
\hline Emotions & $\begin{array}{l}\text { Establishment of emotional bond with stakeholders to obtain a personal } \\
\text { connection }\end{array}$ \\
\hline
\end{tabular}

Source: Authors' adaptation to the research of Spear and Roper (2013).

The population was identified from CBF's official website to get rankings for 2014. After this first survey, the authors browsed the site of each selected club, interacting with it as required for the analysis of corporate stories. In this study, a corporate story is a form of narrative (corporate storytelling), according to the understandings of Maclnnis and Jaworski (1989), Cunliffe et al., (2004) and Ling et al., (2010), which recounts events logically and chronologically, depending on the organization.

Gupta (2012), states that the communication of corporate stories may vary. This paper used solely the corporate stories presented on the official web sites of football teams under study. For several authors (CHUNG, 2012; MAITY et al., 2012; WHITING and WILLIAMS, 2013) web sites may draw out strong feelings towards the brand and can be a vital part of an organization's communication with its market.

The web sites studied contain diverse formatting with regard to design, showing tabs named in different ways, but containing similar information. For example, most teams present a tab called "Management" with information regarding to the organizational structure of the management team and the key roles of employees. With very similar content, some clubs called this 
tab "Administration" and some called it "About Us". Therefore, the authors used an extensive preliminary study to equalize analysis of this corporate communication tool. The tabs of each club were downloaded, divided by similarity of name and information and then reclassified. The names found (now equalized) were celebrations, fans space, stadium, statistics, management, history, games, store, news, squad, social network, tv/radio, and values. Not all of these are related to corporate stories.

The pages containing corporate stories in whole or in fragments were separated from the remaining tabs. The authors then proceeded with the content analysis of the selected tabs, initially performing what Bardin (2010) suggests as a brief reading, in which contact is established with all texts without observing rules or ordering, but searching for impressions and preliminary guidelines. In this sense, the reading aimed at identifying similarities among ideas put forward/communicated/reported by clubs, identifying possible contexts and scenarios in which corporate stories could have been written.

Then, excerpts of texts were classified in units of record "Activities", "Benefits" and "Emotions". These excerpts are called context units, which are content that facilitates understanding of the significance of the message, according to Bardin (2010), and can be words, phrases, sentences or paragraphs. In this study, the authors chose phrases, because they indicate more accurately the context in which the message content is. The sentences were arranged in Excel file software, in order to facilitate viewing and indexing the units of record. From this phase forward, content analysis of classified messages was initiated.

\section{DATA ANALYSIS}

The websites of football clubs in series A, B, and C, participants of the Brazilian championship in 2014, totaling 60 clubs, were screened to meet the objective of this study. All websites had evidence of corporate stories. Some of them were documented in more than one tab, with or without repetition of content.

From what has been previously established as corporate stories and themes (Activities, Benefits and Emotions), Table 1 was developed, in which all of the clubs' websites were analyzed to establish which elements of corporate stories were presented. The elements constituted long corporate stories, featured on more than one page of text, and often in more than one tab. For some clubs, however, corporate elements are short stories, with few arrangements among them and the use of only one or two website tabs.

Table 1

Themes and elements identified in corporate stories

\begin{tabular}{|l|l|l|}
\hline Corporate story theme & Corporate story elements & $\begin{array}{l}\text { CBF football teams with } \\
\text { elements of corporate } \\
\text { stories (\%) }\end{array}$ \\
\hline 1. Activities & 1.1 Activities & 85,00 \\
\hline & 1.2 Skills & 51,67 \\
\hline & 1.3 Mission and vision & 10,00 \\
\hline 2. Benefits & 1.4 Values & 8,33 \\
\hline & 2.1 Internal benefits & 3,33 \\
\hline 3. Emotions & 2.2 External benefits & 75,00 \\
\hline & 3.1 Emotions & 93,33 \\
\hline & 3.2 Battles and solutions & 85,00 \\
\hline & 3.3 Conflicts & 63,33 \\
\hline
\end{tabular}

Source: Compiled from football teams websites by the authors, 2014. 
Different elements were used by clubs individually and with extensive variation among them. This indicates that some elements are more important than other for different clubs during the process of constructing corporate stories.

Recording the theme Activities, the highest percentage of use was the element "activities", with $85 \%$ of clubs showing this element. Also with a significant percentage, the element "skills" was used in $51.67 \%$ of the websites.

By using the element "activities", the club frankly responds to what is expected of any organization: processes and procedures that generate results, which involves the adoption of a set of actions. Basically, people believe that hard work garners great results, according to the understanding of Collins (2013). The websites demonstrates the idea of activity as a precursor to good results on the pitch:

Off the match pitch, the club defied critics and logic and built the largest private stadium in Brazil, the Morumbi stadium. It has continued its pioneering investment in infrastructure as a pillar of excellence in the sport, building over time its Training Center and Athletes Training Center. The result? The world has seen three times (SÃO PAULO - Series A),

an allusion to the three-time world championship status obtained by the team. In this sense, the football team states that because of their external activity, they obtained results internally on the football pitch.

The element "skills" complements "activities". One of the websites states: "Its mystique of revealing talents and of having been the birthplace of the greatest athlete of all times, King Pele, the team became known worldwide" (SANTOS - Series A), in which it commented on the ability to discover talents that allowed the team to obtain titles and recognition. In a quote from another website: "Using strategic long-term planning and a modern management concept, the club is one of the landmarks of Brazilian football management and administration" (JUVENTUDE - C series), in which the ability to plan, to keep the team organized and ready, and to get positive results on the pitch is visible.

In the Benefits theme, the element "external benefits" was present in 75\% of clubs and "internal benefits" in only $3.33 \%$ of them.

The external benefits are usually directed to fans or potential fans. One of the websites communicated directly with fans, showing advantages in being a member:

Rabbit Club Member, whereby becoming a member of JEC, you can come for free! The Rabbit Club is an exclusive benefit for members of the Joinville Esporte Clube. Commercial establishments accredited by JEC offer special discounts to members. By using the Rabbit Club, members save on their daily expenses and may even have free membership. More than 40 establishments are already accredited by the Rabbit Club (JOINVILLE - B series).

Marketing efforts by Rabbit that clearly bring benefits tend to get quick results and allow the undecided consumer to compare the company's proposed offerings with its competitors. This can be confirmed by the literature, as can be seen in Suvatjis (2012).

Even with very low incidence being found on the websites, a project which focuses on the member of the club is noteworthy:

What is the tricolor Generation Institute? An educational institution that seeks to guarantee the right to childhood and adolescence, overcoming vulnerability, promoting leadership and effective exercise of citizenship of children and adolescents in socioeconomic vulnerability. It targets an audience of children and adolescents between 6 and 14 years old in social and economic vulnerability, children of employees and family of athletes (GRÊMIO - Series A).

Besides the fact that the club is a social entity and, therefore, gives to and receives something from society, there is also the aspect of recognizing the efforts from people who help the club grow. However, attempts to act free of commercial interest and with selfless social initiatives to garner interesting results for competitive sports, clubs are not always successful, such as the aforementioned Santos “(...) mystique of revealing talents and to have been the birthplace of the greatest athlete of all times (...)". And, often, the organization may not be looking for such results. Gupta (2012) understanding is that, far from being a philanthropic action, it is a set of interests in search of a better world and genuine proactive participation of the organization in this world. 
In the Emotions theme, the elements "emotions" and "battles and solutions" obtained a high rate of participation in the websites, with 93.33\% and 85\%, respectively. The "conflict" element had participation of 63.33\%, and the element "fantasy", 48.33\%.

Among the three, this was the theme that had the highest participation. Separately, two elements obtained the largest share of the entire survey ("emotions", "battles and solutions" and "conflict" had the fourth highest participation). Even the least present element "fantasy", is in almost half of the websites of the football teams in series A, B and C. Given the passionate connection between fans and football teams, it is the most obvious result.

The element "emotions", with a high 93.33\% appearance on the websites of the clubs, represents the strongest link between people and their favorite sport. In football, it is even stronger, considering the broad media coverage. Woodside (2010) argues that the available literature on storytelling emphasizes the importance of emotions in any story, first for establishing a connection between the reader and writer, and second by allowing surprises and unexpected approaches within the narrative. One of the clubs does it by telling a great achievement:

(...) In the next phase, 0-0 with Vasco in Rio de Janeiro, and 1-0 in São Paulo, with a head goal from the midfielder Paulinho, that will remain forever in the memory of fans. After the tie at 1-1 in Buenos Aires city in the first game of the final, we beat Boca Juniors of Argentina, with two goals from forward Emerson, who led the crowd to scream the champion chorus of Libertadores for the first time in history. In a flawless campaign, the club from Parque São Jorge defeated eight opponents and drew six duels (CORINTHIANS - A series).

The use of terms as "(...) will remain forever (...)" or "(...) led the crowd to scream (...)" or "(...) flawless campaign (...)" refers to the excitement fans felt on that day and these feelings return when they read the story again. A story retold with an emotional connection transports readers to the same location in which they were and broadens the joy previously felt, according to Dewaele (2004). It can also make such feelings an unforgettable aspect, as stated in the phrase referring to the state of eternal permanence of affective memory in the minds of fans, referring to a head goal, in the semifinals of the championship.

Another football team, in its website, tells of the thrill of reaching their first final in a national competition. Considered a small team, facing well-invested teams with international recognition, telling thus:

(...) After a draw of three goals in Palestra Italia, São Caetano boarded a plane to Rio de Janeiro city, where they would face Fluminense at the giant Maracanã stadium. Even with 70,000 opponent fans, Adhemar secured a 1-0, and became known as "Anacleto Campanella's Cannon" - the name of the club's stadium - and led the team forward in the competition. The small becomes giant, after eliminating Palmeiras and Gremio, and reaching the final. Despite not becoming champion, the team gained national prominence and was considered by other fans as the moral winner of the competition (SÃO CAETANO - C series).

The word "giant", used twice in different situations, and the assertion that the football team, for their brilliant campaign, morally should have become champion, raised the excitement to its maximum, bringing fans into the action again, recalling what happened that year. As Dowling (2006) points out, less prestigious actors in a narrative can become protagonists, depending on how the story is told. On the other hand, according to Van Riel and Fombrun (2007), the image of an organization is defined in a real way as occurs an incorporation by the consumer, making it a pragmatic effect.

The element "battles and solutions", with $85 \%$ share on the websites, brings the emotional aspect, but is basically about major battles, epic wins, those moments the clubs went through and when they had to display all their courage when facing a challenging situation. One of the established clubs defined one of its fights:

In the Libertadores Championship in 1981, the most beloved club - as Flamengo is known in Brazil enters the pitch with a flag of Uruguay, in Montevideo Centenario Stadium, determined to defeat the violent Cobreloa team and win the South American title. [ ... ] On that day, beautiful football beat the violent football of the Chilean team (FLAMENGO - Series A).

Two elements are key to understanding. The first concerns to aspects involved: calling itself by a nickname - the most beloved, bringing the flag of the country who hosted the final game, and commenting on the violent performance of the Chilean team. The second is the rescuing the now Brazilian custom of calling its own style of football - beautiful football - to show that victory over violence was difficult, hard, exhausting, but valuable. For Green et al., (2008), heroes and villains are part of well-constructed narratives and their absence may mean that the story has no emotional resonance typical of big wins. 
The element "conflicts" is well represented in two narratives:

In 1911, players from Fluminense, state champions that year in Rio de Janeiro, gathered in a boarding house and decided to leave the club, taking the football team to another club: Clube de Regatas do Flamengo, so far without a football team (FLAMENGO - Series A)

and

Santa Cruz was born red-and-black. The choice of black and white is a representation of the ideal of the club: to gather fans of all races, because until the foundation of Santa Cruz, blacks and mestizos were forbidden to join the cast of other teams in the capital (SANTA CRUZ - B Series).

Both cases represent aspects related to conflicts and tell a story that captivates readers due to the force of events. A story on how a rowing club became a football club, now one of the largest group of fans in the world (approximately 40 million fans, according to Pluri Stochos in 2013), and another story about the color of the uniform are means of communicating against racial discrimination. The image created by the organization is understood in different ways by different groups at different times. Van Riel and Fombrun (2007) argue that the assessment of organizational effectiveness, currently involves the ability to design and maintain a strong image.

The element "fantasy" showed a high level of representativeness on the websites, although smaller than the other elements in its theme. Still, the composition of corporate stories would not be as interesting without this one. The fanciful elements, for Brown et al., (2009), are important components of corporate stories because they usually unite all elements around a single focal point. On the websites, there are several fanciful aspects, and one that best represents the element is:

The Paysandu Sport Club mascot was created in 1948 by a journalist code-named "bicho-papão" (boogeyman, in English). The inspiration of the journalist was the fear that the Steel Squad, as the team was known at that time, rousing their opponents on the pitch. With time, it became known as the "Boogey of Curuzu", the greatest conqueror of football titles in Northern Brazil (PAYSANDU - C series).

In Brazil, "bicho-papão" is a monster that scares children, mainly, and Curuzu is the region where the club is. When corporate stories combine fantasy with reality, they seek pictorial elements that allow the fan to engage with the narrative more didactically. For Collins (2013), elements which individually might not make sense, when well arranged in a narrative create the illusion of reality for those reading. According to Van Riel and Fombrun (2007), the receiver individual comprises the image as a constituent of a truth about what is seen and touched.

\section{CONCLUSION}

The aim of this study was to investigate the content of corporate stories of football teams in Brazil and how these stories are used by football teams to build their corporate brand.

One of the most used platforms of communication as source of information and references nowadays is the internet. In this sense, websites are the perfect channels to record accomplishments, achievements, news, results and other organizational interests, to allow the reader to find out what companies want to promote. Besides the low cost, a websites is the channel that allows for quick updates, due to its production process.

From content analysis of websites of Brazilian football clubs of series A, B and C, it is observed that the most common theme is Emotion. Composed, in this study by the elements "emotions", "battles and solutions", "conflict" and "fantasy", the theme is linked to sport, usually a free and extensive exposure activity. By its nature, it is wrapped in victory, sweat, the shedding of tears, stress and resilience, the sport is filled with these feelings.

The clubs have understood this condition and openly use the elements of each theme to build corporates stories, and; therefore, form their corporate brand. Although it has not been studied, nor is it the focus of this paper, it is noteworthy that the very definitions of popular football clubs have been developed based on those feelings and have become emotional nicknames 
for the clubs' brands. Thus, the "most beloved" for Flamengo or "bigteam" for Corinthians, or "Lion of the Island" to Avai or "suburban tricolor" for Madureira, are commonly used among fans and often by the media.

Emotion is the only constant element in relations among fans and football teams (other variables might be recognized by certain members of the group, evaluation of results on the pitch due to the monthly fee paid for membership, demands for minimum recreational conditions at the social club, among others). Therefore, a corporate brand that uses emotions expressed in corporate stories has its development aligned with the desires and behavior of fans.

The theme Activities, composed of four elements, but with only two of them being strongly represented in the survey, namely "activities" and "skills", represents the rational part of the corporate brand. It is understandable that in the process of building a brand, functional attributes are strongly taken into consideration. They, after all, demonstrate the results obtained through work, through strategic and operational actions, and through joint efforts to structurally grow sports. They are usually easier to measure, and a relevant factor when getting a high appearance rate in the corporate stories of clubs.

It should be taken into consideration that the teams use space on websites to publicize the actions of their Board, both in the organizational field, as in sports. As a channel of communication quickly updated and without pre-defined space, the website is ideal to present strategic and operational achievements to fans and others. These achievements, along with other aspects, form a corporate brand.

The findings show that corporate stories told through emotions and activities on the clubs' websites form the corporate brands of football teams, when looked at from the digital perspective.

\section{ACADEMIC AND MANAGERIAL IMPLICATIONS}

Studies of this nature bring academic implications. Among them, it broadens the research field for other sources of corporate stories, such as institutional advertising or annual social reports. Researchers can identify to what extent these other sources influence the building of a corporate brand compared with the findings here obtained, expanding knowledge about corporate stories as having influence on the building of corporate brands. Another implication relating to the use of this study is in the further awareness of how various stakeholders (fans, media and non-fans) have been building their own understandings about the corporate brand from corporate stories of teams on the websites.

Among managerial implications, football teams can invest professionally in the development of their websites, aiming at adding to their website corporate stories with new facts, more often. In particular, the elements of activities and skills, from a rational point of view, and battles and solutions, from an emotional point of view, can be translated into important aspects of brand valuation, when well conducted.

New products, regular or celebratory (dates or achievements), can be developed based on corporate stories. These products, as clothes, dolls, visitation programs, themed restaurants or ambient experiences, can produce substantial revenue for the club, and simultaneously reinforce the identity of the football team.

Among other implications, the fact that corporate stories are in the tabs of the websites may potentially inhibit reading by the fans. From a managerial perspective, it is recommended that teams overhaul their websites, providing simple and direct access to users. This procedure will bring more visibility and responsiveness for the corporate brand of the football team.

\section{LIMITATIONS}

Studies seeking information in sources of organizational communication, like advertising or websites, may present the company version of the facts, but it is not always the version that the reader has in mind. Therefore, the fact of not dialoging with stakeholders, including internal ones, may represent a limitation and point out the possibility of other findings for the same subject of study. The fact that the study has expanded its sample to three series of Brazilian football, make a direct comparison of the results difficult, because of the varying conditions between one series and another, especially regarding the resources paid by television to broadcast the games and, possibly in the way they build their corporate stories. 


\section{REFERENCES}

ABRATT, R.; KEYN, N. Corporate identity, corporate branding and corporate reputations: reconciliation and integration. European Journal of Marketing, v. 46, n. 7/8, p. 1048-1063, 2012.

BAKER, B.; BOYLE, C. The timeless power of storytelling. Journal of Sponsorship, v. 3, n. 1, p. 79-87, 2009.

BARDIN, L. Análise de conteúdo. Lisboa: Edições 70, 2010.

BROWN, T. J. et al. Identity, intended image, construed image, and reputation: an interdisciplinary framework and suggested terminology. Journal of the Academy of Marketing Science, v. 34, n. 2, p. 99-106, 2006.

BROWN, A. D.; GABRIEL, Y.; GHERARDI, S. Storytelling and change: an unfolding story. Organization, v. 16, n. 3, p. 323-333, 2009.

CBF Confederação Brasileira de Futebol web site. Available at: <www. cbf.com.br>. Accessed on:: January 13. 2014.

CHUNG, K-C. Antecedents of brand trust in online tertiary education: a tri-nation study. Journal of Global Scholars of Marketing Science, v. 22, n. 1, p. 24-44, 2012.

COLLINS, D. In search of popular management: sensemaking, sensegiving and storytelling in the excellence project. Culture and Organization, v. 19, n. 1, p. 42-61, 2013.

CUNLIFFE, A. L.; LUHMAN, J. T.; BOJE, D. M. Narrative temporality: implications for organizational research. Organisation Studies, v. 25, n. 2, p. 261-286, 2004.

De CHERNATONY, L.; COTTAM, S.; SEGAL-HORNJ, S. Communicating services brands' values internally and externally. Service Industries Journal, v. 26 n. 8, p. 819-836, 2006.

DEWAELE, J-M. The emotional force of swearwords and taboo words in the speech of multilinguals. Journal of Multilingual and Multicultural Development, v. 25, n. 2/3, p. 204-222, 2004.

DOWLING, G. Communicating corporate reputation through stories. California Management Review, v. 49, n. 1, p. 82-100, 2006.

DURIAL, V. J.; REGER, R. K.; PFARRER, M. D. A content analysis of the content analysis literature in organization studies. Organizational Research Methods, v. 10, n. 1, p. 5-34, 2007.

ESCALAS, J. E. Self-referencing and persuasion: narrative transportation versus analytical elaboration. Journal of Consumer Research, v. 33, n. 4, p. 421-429, 2007.

FETSCHERIN, M.; USUNIER, J. Corporate branding: an interdisciplinary literature review. European Journal of Marketing, v. 46, n. 5, p. 733-753, 2012.

FIFA Fédération Internationale de Football Association web site. Available at: <pt.fifa.com>. Accessed on:: January 13. 2014.

GASKI, J. F.; ETZEL, M. The index of consumer sentiment toward marketing. Journal of Marketing, v. 50, n. 3, p. 71-81, 1986.

GREEN, M. C. et al. Transportation across media: repeated exposure to print and film. Media Psychology, v. 11, n. 4, p. 512-539, 2008.

GUPTA, S. Interdependence between experience marketing and business strategy. Journal of Indian Business Research, v. 4, n. 3, p. 170-193, 2012.
JANSSEN, S. et al. Balancing uniqueness and similarity: a content analysis of textual characteristics in Dutch corporate stories. Public Relations Review, v. 38 n. 1, p. 32-39, 2012.

KRIPPENDORFF, K.; BOCK, M. A. The content analysis reader. Thousand Oaks: Sage, 2008.

LING, K. C.; PIEW, T. H.; CHAI, L. T. The determinants of consumers' attitude towards advertising. Canadian Social Science, v. 6, n. 4, p. 114-126, 2010.

MacINNIS, D. J.; JAWORSKI, B. Information processing from advertisements: toward an integrative framework. Journal of Marketing, v. 53, n. 3, p. 1-23, 1989

MAI, L-W.; SCHOELLER, G. Emotions, attitudes and memorability associated with TV commercials. Journal of Targeting, Measurement and Analysis for Marketing, v. 17, n. 1, p. 55-63, 2009.

MAITY, M.; HSU, M. K.; PELTON, L. E. Consumers' online information search: genyers' finding needles in the internet haystack. Journal of Marketing Channels, v. 19, n. 1, p. 49-76, 2012.

PluriStochos 2013. 1a. pesquisa PluriStochos tamanho de torcidas. Available at: <www.stochos.com.br>. Accessed on:: March 20. 2014.

PORTER, M. Competitive advantage. New York: The Free Press, 1985.

ROPER, S.; FILL, C. Corporate reputation: brand and communication. Harlow: Pearson, 2012.

SPEART, S.; ROPER, S. Using corporate stories to build the corporate brand: an impression management perspective. Journal of Product \& Brand Management, v. 22, n. 7, p. 491-501, 2013.

SRINIVASAN, S.; VANHUELE, M.; PAUWELS, K. Do mind-set metrics explain brand sales? Journal of Marketing Research, v. 47, n. 4, p. 672-684, 2010.

SRIVASTAVA, R. K.; SHERVANI, T. A.; FAHEY, L. Market-based assets and shareholder value: a framework for analysis. Journal of Marketing, v. 62, n. 1 , p. 2-18, 1998.

SUVATJIS, J.; CHERNATONY, L. de; HALIKIAS, J. Assessing the six-station corporate identity model: a polymorphic model. Journal of Product \& Brand Management, v. 21, n. 3, p. 153-166, 2012.

VAN RIEL, C. B. M.; FOMBRUN C. J. Essentials of corporate communication: implementing practices for effective reputation management. New York: Routledge, 2007.

WHITING, A.; WILLIAMS, D. Why people use social media: a uses and gratifications approach. Qualitative Market Research: An International Journal, v. 16, n. 4, p. 362-369, 2013.

WOODSIDE, A.G. Brand-consumer storytelling theory and research: introduction to a psychology and marketing special issue. Psychology and Marketing, v. 27 n. 6, p. 531-540, 2010.

WYER, R. S.; XU, A. J. The role of behavioral mindsets in goal-directed activity: conceptual underpinnings and empirical evidence. Journal of Consumer Psychology, v. 20, n. 1, p. 107-125, 2010. 


\section{REFERENCES OF RESPONDENTS CLUBS}

ABC. Available at: <http://www.abcfc.com.br/\$>. Accessed on: on: March 22, 2014.

AGUIA. Available at: <http://www.aguiademaraba.com.br/index2. htmß. Accessed on: on: March 24, 2014.

AMÉRICA DE NATAL. Available at: <http://www.americadenatal.com. br/\$. Accessed on: on: March 22, 2014.

AMÉRICA MINEIRO. Available at: <http://www.americamineiro.com. br/P. Accessed on: on: March 22, 2014.

ASA. Available at: <http://www.asa-arapiraca.com.br/P. Accessed on: March 24, 2014.

ATLÉTICO GOIANIENSE. Available at: <http://www.atleticogoianiense. com.br/>. Accessed on: March 22, 2014.

ATLÉTICO MINEIRO. Available at: <http://www.atletico.com.br/site/>. Accessed on: March 20, 2014.

ATLÉTICO PARANAENSE. Available at: <http://www.atleticoparanaense.com/>. Accessed on: March 20, 2014.

AVAI. Available at: <http://www.avai.com.br//>. Accessed on: March 20, 2014

BAHIA. Available at: <http://www.esporteclubebahia.com.br/\$ . Accessed on: March 20, 2014.

BOA ESPORTE. Available at: <http://www.boaec.com.br/\$. Accessed on: March 20, 2014.

BOTAFOGO DA PARAIBA. Available at: <http://www.botafogodaparaiba.com/\$. Accessed on: March 20, 2014.

BOTAFOGO. Available at: <http://www.botafogo.com.br/P. Accessed on: March 20, 2014.

BRAGANTINO. Available at: <http://www.bragantino.net/>. Accessed on:: March 20, 2014.

CAXIAS. Available at: <http://www.sercaxias.com.br/>. Accessed on: March 20, 2014.

CEARA. Available at: <http://www.cearasc.com>. Accessed on March 20, 2014

CHAPECOENSE. Available at: <http://www.chapecoense.com/site/>. Accessed on: March 20, 2014.

CIANORTE. Available at: <http://www.cianortefc.com.br/p. Accessed on: March 20, 2014.

CORINTHIANS. Available at: <http://www.corinthians.com.br/site/ home/>. Accessed on: March 20, 2014.

CORITIBA. Available at: <http://www.coritiba.com.br// . Accessed on: March 20, 2014.

CRB. Available at: <http://www.crb.esp.br//>. Accessed on: March 24, 2014

CRICIUMA. Available at: <http://www.criciumaec.com.br>. Accessed on: March 20, 2014.
CRUZEIRO. Available at: <http://www.cruzeiro.com.br/index.php?section=home $>$. Accessed on: March 20, 2014.

CUIABÁ. Available at: <http://www.cuiabaesporteclube.com.br/P. Accessed on: March 24, 2014.

DUQUE DE CAXIAS. Available at: <http://www.souduque.com.br/\$ . Accessed on: March 24, 2014.

FIGUEIRENSE. Available at: <http://www.figueirense.com.br//> Accessed on: March 20, 2014.

FLAMENGO. Available at: <http://www.flamengo.com.br/>. Accessed on: March 21, 2014.

FLUMINENSE. Available at: <http://www.fluminense.com.br// Accessed on: March 21, 2014.

FORTALEZA. Available at: <http://www.fortalezaec.net/>. Accessed on: March 24, 2014.

GOIAS. Available at: <http://www.goiasesporteclube.com.br/p. Accessed on: March 21, 2014.

GREMIO. Available at: <http://www.gremio.net/>. Accessed on: March 21, 2014.

GUARANI. Available at: <http://www.guaranifc.com.br/\$. Accessed on: March 24, 2014.

GUARANTIGUETÁ. Available at: <http://www.guarafutebol.com.br/\$. Accessed on: March 25, 2014.

ICASA. Available at: <http://www.icasafc.com/>. Accessed on: March 22, 2014.

INTERNACIONAL. Available at: <http://www.internacional.com.br/ home.php>. Accessed on: March 21, 2014.

IPATINGA. Available at: <http://ipatingafc.com.br/plus/>. Accessed on: March 25, 2014.

JOINVILLE. Available at: <http://www.jec.com.br/P. Accessed on: March 22, 2014.

JUVENTUDE. Available at: <http://www.juventude.com.br/P. Accessed on: March 25, 2014.

LUVERDENSE. Available at: <http://www.luverdense.com.br//> Accessed on: March 23, 2014.

MACAÉ. Available at: <http://www.macaeesporte.com.br/>. Accessed on: March 25, 2014.

MADUREIRA. Available at: <http://www.madureiraec.com.br//>. Accessed on: March 25, 2014.

MOGI MIRIM. Available at: <http://www.mogimirim.com.br/>. Accessed on: March 25, 2014.

NAÚTICO. Available at: <http://www.nautico-pe.com.br/>. Accessed on: March 23, 2014.

OESTE. Available at: <http://www.oestefc.com.br/>. Accessed on: March 23, 2014. 
Corporate brand building from the corporate stories perspective: a Brazilian football teams study
Edson Roberto Scharf | Francisco Giovanni David Vieira Richard Perassi Luiz de Sousa | Edimar Russi
PALMEIRAS. Available at: <http://www.palmeiras.com.br/home/\$. Accessed on: March 21, 2014.

PARANÁ. Available at: <http://www.paranaclube.com.br/P. Accessed on: March 23, 2014.

PAYSANDÚ. Available at: <http://www.paysandu.com.br/P. Accessed on: March 25, 2014.

PONTE PRETA. Available at: <http://www.pontepreta.com.br/\$ . Accessed on: March 23, 2014.

PORTUGUESA. Available at: <http://www.portuguesa.com.br/>. Accessed on: March 23, 2014.

SALGUEIRO. Available at: <http://www.salgueiroac.com/>. Accessed on: March 25, 2014.

SAMPAIO CORREIA. Available at: <http://www.sampaiocorreafc. com.br/P. Accessed on: March 23, 2014.

SANTA CRUZ. Available at: <http://www.santacruzpe.com.br// Accessed on: March 23, 2014.

SANTOS. Available at: <http://www.santosfc.com.br//>. Accessed on: March 21, 2014.
SÃO CAETANO. Available at: <http://www.adsaocaetano.com.br/\$. Accessed on: March, 25. 2014.

SÃO PAULO. Available at: <http://www.saopaulofc.net/>. Accessed on: March 21, 2014.

SPORT. Available at: <http://www.sportrecife.com.br/>. Accessed on: March 21, 2014.

TREZE. Available at: <http://www.trezefc.com.br//>. Accessed on: March 25, 2014.

TUPI. Available at: <http://www.tupijf.com.br/P. Accessed on: March 25, 2014.

VASCO. Available at: <http://www.vasco.com.br//>. Accessed on: March 23, 2014.

VILA NOVA. Available at: <http://www.vilanovafc.com.br/P. Accessed on: March 23, 2014.

VITÓRIA. Available at: <http://www.ecvitoria.com.br/>. Accessed on: March 21, 2014.

Edson Roberto Scharf

$\mathrm{PhD}$ in Engineering and Knowledge Management in the Marketing area from the Federal University of Santa Catarina (UFSC); Professor at the Postgraduate Program in Administration (PPGAD) of FURB, Blumenau - SC, Brazil. E-mail: artigoes@gmail.com

Francisco Giovanni David Vieira

PhD in Social Sciences from the Pontifical Catholic University of São Paulo (PUC-SP); Associate Professor at the Postgraduate Program in Administration (PPA) of UEM, Maringá - PR, Brazil. E-mail: fgdvieira@uem.br

Richard Perassi Luiz de Sousa

PhD in Communication and Semiotics from the Pontifícal Catholic University of São Paulo (PUC-SP); Professor at the Postgraduate Program in Engineering and Knowledge Management (PPGEC), UFSC, Florianópolis - SC, Brazil. E-mail: richard.perassi@uol.com.br

Edimar Russi

Master in Business Administration from the University of Blumenau (FURB); Professor at the Administration Department of FURB, Blumenau - SC, Brazil. E-mail: edimar.russi@gmail.com 